\title{
Asthma diagnosis and treatment - 1011. OZAC- a herbal medicine for bronchial asthma
}

\author{
Hari Kishan Gonuguntla*, Parankusam Rao, Bhukya Naik \\ From 2nd WAO International Scientific Conference (WISC 2012) \\ Hyderabad, India. 6-9 December 2012
}

\section{Background}

To assess the efficacy of a herbal medicine made up of ocimum sanctum,zingiber officinale, azadirachta indica, curcuma longa in a titrated combination tablet prepared by 'IMMIS' labs, India for bronchial asthma patients.

\section{Methods}

100 subjects suffering from bronchial asthma were enrolled for this study from 2012 January to February, after obtaining consent of the participants and ethical committee approval. The bronchial asthma severity was graded as severe pefr $<2001$ trs $\backslash \mathrm{Mt}$, moderate 200-300ltrs $\backslash \mathrm{Mt}$, mild 300-400ltrs $\backslash \mathrm{Mt}$. For this study moderate and mild categories were selected. Furthermore 20\% (10\% each of moderate and mild) were considered as control.

All the ingredients of OZAC together have the pharmacological action of bronchodilatation, antiallergic , mucolytic and antihistaminic properties. The entry samples were assessed with Wrighst peak flow meter before and after the observation period of three weeks, besides the subjective evaluation. As and when required they were administered long acting fluticasone+fometerol (FF), short acting salbutamol (SI) aerosol with an internal spacer TOPS (trans oro pharyngeal spacer) and doxophylline tabs (400mg).

\section{Results}

1. The entire sample consisted of 70 males and 30 females within the age range of 15 to 80 years.

2 . The mild group (45\%) required 2 tabs of ozac twice daily and FF inhaler one puff daily. The improvement in the pefr (15\%)-pre and post treatment was significant $(\mathrm{p}<.001)$.

Pulmonology, Katuri Medical College \& Hospital, Guntur, India
3. The moderate group had 2 tabs of ozac twice daily+ FF BID+ Salbutamol sos. The reversibility was significant $(\mathrm{p}<.001)$.

4. The control group moderate and mild required FF +SI+doxophylline (400mg bid).

\section{Conclusions}

Ozac has distinct advantage in the treatment of bronchial asthma. The unique properties of its ingredients makes it an effective adjuvant to the asthma medication.

1. It reduces the need of the inhalers and other bronchodilators

2. It induces confidence in the users

3. It is cost effective and can be an effective adjuvant

4. There are no reported side effects.

Published: 23 April 2013

doi:10.1186/1939-4551-6-S1-P11

Cite this article as: Gonuguntla et al:: Asthma diagnosis and treatment 1011. OZAC- a herbal medicine for bronchial asthma. World Allergy Organization Journal 2013 6(Suppl 1):P11.

Submit your next manuscript to BioMed Central and take full advantage of:

- Convenient online submission

- Thorough peer review

- No space constraints or color figure charges

- Immediate publication on acceptance

- Inclusion in PubMed, CAS, Scopus and Google Scholar

- Research which is freely available for redistribution

(c) 2013 Gonuguntla et al; licensee BioMed Central Ltd. This is an Open Access article distributed under the terms of the Creative 